Raimund Bleischwitz, Monika Dittrich, Chiara Pierdicca

\title{
Coltan from Central Africa, international trade and implications for any certification
}

Originally published as:

Raimund Bleischwitz, Monika Dittrich, Chiara Pierdicca (2012):

Coltan from Central Africa, international trade and implications for any certification In: Resources Policy, 37, 1, 19-29 
Raimund Bleischwitz ${ }^{a,{ }^{*}}$, Monika Dittrich, Chiara Pierdicca ${ }^{b}$

\section{Coltan from Central Africa, international trade and implications for any certification}

a Wuppertal Institute for Climate, Environment and Energy, Germany

${ }^{b}$ College of Europe, European Economic Studies Department, Belgium

* Corresponding author: Raimund Bleischwitz, Wuppertal Institute for Climate, Environment and Energy, Döppersberg 19, 42103 Wuppertal, Germany

E-mail: raimund.bleischwitz@wupperinst.org

Phone: +49-(0)202-2492-256

Fax: $+49-(0) 202-2492-108$ 
Raimund Bleischwitz, ${ }^{1}$ Monika Dittrich, Chiara Pierdicca ${ }^{+}$

\section{Coltan from Central Africa, international trade and implications for any certification}

December 20, 2011, accepted for publication in: Resources Policy (Elsevier, 5-year impact factor 1.190)

\section{Abstract}

The exploitation of coltan in Central Africa can be considered a case of conflict minerals due to its nature. Many international organizations and bodies, national governments and private sector organizations seek to address this conflict, in particular via transparency, certification and accountability along the material supply chain. This paper analyses the international trade dimension of coltan and gives evidence on the dimension of illicit trade of coltan. The authors start from the hypothesis that illicit trade of coltan sooner or later will enter the market and will be reflected in the statistics. The paper is structured in the following manner: first, a short section gives a profile of coltan production and markets; second, an overview of the mining situation in the Democratic Republic of Congo (DRC) and related actors. The third section addresses mechanisms, actors and measurement issues involved in the international trade of coltan. The final part draws lessons for certification and conflict analysis and offers some guidance for future research.

The paper identifies two main possible gateways to trace illegal trade in coltan: the neighboring countries, especially Rwanda, and the importing countries for downstream production, in particular China. Our estimation is that the value of such illicit trade comes close to \$27 million annually (2009), roughly one fifth of the world market volume for tantalum production. With regard to any certification the paper concludes that this will become challenging for business and policy: (a) Central Africa currently is the largest supplier of coltan on the world market, many actors profit from the current situation and possess abilities to hide responsibility; (b) China will need to accept more responsibility, a first step would be the acceptance of the OECD guidelines on due diligence; (c) better regional governance in Central Africa comprises of resource taxation, a resource fund and fiscal coordination. An international task force may provide more robust data, however more research will also be needed.

Keywords: coltan, certification, central africa, raw materials conflict, international trade

JEL-Code: F14, K42, N50, O19, Q33

\footnotetext{
${ }^{1}$ Corresponding author, address: Wuppertal Institute for Climate, Environment and Energy, Döppersberg 19, 42103 Wuppertal, Germany, email: raimund.bleischwitz@wupperinst.org. We wish to thank Gudrun Franken, Philip Schütte, Frank Melcher (all BGR), John F. Papp (USGS), Natalie Harms, and Stacy VanDeveer as well as an anonymous reviewer for useful comments; Raimund Bleischwitz appreciates support from the Transatlantic Academy in Washington DC in 2011-12.

${ }^{+}$College of Europe, Bruges/Belgium.
} 


\section{Introduction}

Coltan mining in Central Africa and especially in the Eastern Kivu region of the Democratic Republic of Congo (DRC) has often been viewed as a case for a conflict over the control of raw materials in a fragile state ${ }^{2}$. Although the DRC see to advance in some key areas lately, e.g. in macro-economic management, education enrolment or improving drinking water supply (UNEP, 2011), it remains one of the poorest countries world-wide (UNDP, 2011). Rebel groups and others go on fighting over access to minerals and profit from illicit trade, and the state still fails to provide sufficient social order resulting in unchecked criminal activities. The easy access to coltan and other minerals, combined with weak property rights in a country with weak basic institutions and a long history of civil war, and a high demand on world markets can be assumed as main determinants of insecurity and conflicts, especially in the eastern Congo (Nest 2011: 71ff.).

There is a clear pledge for international action from various sides. The United Nations have established evidence and given recommendations by means of several Expert reports. The most recent one (S/2010/596) and the ensuing UN Security Council resolution (S/RES/1952) of late 2010 call on governments, markets and companies to establish sound systems of supply chain management as well as to impose asset freezes and travel bans for groups and individuals involved in the conflict. In a similar spirit, the G8 resolution of Heiligendamm has started a process to establish certified trading chains in minerals production (CTC); a first activity has been the development of a new geochemical method called 'Analytical Fingerprinting' (AFP) since 2006 that will allow exact pinpointing of the extraction source of a mineral used in products. Initiatives have also been taken by the private sector aiming at transparency and improving the traceability along their supply chains. The annex of this paper contains a number of such initiatives. Needless to say, however, all these initiatives are voluntary, pledges and the few commitments are not yet implemented. The willingness to take serious action seems low compared with the pressing situation. However the Dodd-Frank Act in the $\mathrm{USA}^{3}$ proposes registration requirements for conflict minerals including coltan from that region. In Europe, the European Commission has quite recently introduced a similar proposal ${ }^{4}$ for a country-by-country reporting for large listed and unlisted companies in the extractive and logging sectors.

In order to learn more about the challenges towards transparency and certification, it is the intention of this paper to analyse the international trade dimension of this conflict. The authors acknowledge the work that has been done to analyse the regional conflict and to provide evidence for an involvement of different actors. Doing new analysis on the Kivu region however is beyond the scope of this paper. Based on latest findings and focussing on the international trade dimension, our paper raises the thesis that any certification scheme is faced with a number of challenges. In doing so we address the following issues: What is the dimension of illicit trade? What actors are involved in the international supply chain? What levels of governance need to be addressed? With evidence on the significant amount of illicit trade and the heterogeneity of actors we conclude on activities that would (a) strengthen the institutional

\footnotetext{
${ }^{2}$ According to the World Bank, fragile states are low-income countries scoring 3.2 and below on the Country Policy and Institutional Assessment (CPIA). The term is used for countries with weak institutional capacity, poor governance, and political instability (World Bank 2009). One also finds the term ,failing states ' in the literature; however this indicates a trend towards failing and given some progress in the DRC lately we prefer the term fragile state for the DRC. Stewart and Brown (2009) view the DRC among the worst performers with failure on two dimensions: lack of (1) authority to protect the citizens from violence and (2) provision of access to basic services, with clear implications in terms of poverty reduction. An exhaustive literature review on State fragility is provided in Hannan and Besada (2007).

${ }^{3} \mathrm{http}: / /$ www.sec.gov/spotlight/dodd-frank.shtml

${ }^{4} \mathrm{http}$ ://ec.europa.eu/internal_market/accounting/other_en.htm
} 
robustness of certification and (2) accompanying governance mechanisms that deem necessary.

These issues will be addressed in the following manner: the next two sections will give brief and up-to-date overviews about coltan markets and the mining situation in the DRC. A subsequent section will deal more extensively with international trade of coltan. It addresses mechanisms, actors and measurement issues. The last part will draw lessons for certification scheme and better resource governance and offers some guidance for future research.

Going beyond coltan, a study by the World Economic Forum (2011: 23) refers to illicit trade of minerals in general as a major geopolitical risk with a market size of some US $\$ 20,000$ million annually. Thus we believe that such research is of relevance and part of a larger agenda on resources policy, international economics and sustainable resource management.

\section{Profiling coltan}

Coltan is a term commonly used to refer to columbite-tantalite, a mineral extracted in Central Africa and belongs to a group that is internationally known as tantalum. ${ }^{5}$ This element of the $5^{\text {th }}$ group of the $6^{\text {th }}$ period of the chemical periodical system occurs in the Earth crust with a share of roughly $2 \mathrm{ppm}$ (parts per million), i.e. three times more often than silver. It has a strong geochemical coherence with niobium. The United States Geological Survey (USGS 2011), Roskill (2009) as well as the Tantalum-Niobium International Study Center (TIC) locate large reserves in Australia and Brazil, where new discoveries have been made in recent years. The global reserves were estimated to have been in the order of $110,000 \mathrm{t}$ of contained tantalum in 2011 and considered adequate to meet projected needs. Worth noting: DRC, Rwanda and Ethiopia have not been included in the calculation due to lack of reliable data.

The tantalum industry, characterized by USGS (2009: 52.2) as 'traditionally shrouded in secrecy, ${ }^{6}$ is comprised of (in order of material flow) a mining component that typically extracts ore and produces a concentrate, a processing segment that converts concentrate into an oxide or metal, a parts manufacturing segment that uses the oxide or metal material to produce such components as capacitors or superalloys, and an end-product manufacturing sector that uses the parts, such as capacitors, in electronic devices, such as cellular telephones (USGS 2011: 2). Product range features tantalum oxide, powder, and Tantalum Carbide (TaC). Tantalum is also produced as a byproduct during tin smelting. Research must use all data with caution since they may capture different forms of tantalum. ${ }^{7}$

\footnotetext{
${ }^{5}$ Tantalum minerals comprise e.g. tapiolite, wodginite, ixiolite, bismutotantalite, fermsite, stibiotantalite, simpsonite, microlite and minerals of the complex fergusonite, aeschynite and euxenite mineral groups.

${ }^{6}$ This statement is supported by the facts that there is no spot market / stock exchange price for tantalum and hence price transparency is low, small-scale mines of the Great Lakes Region are not yet documented and partly illegal, the small smelters in China are not yet monitored, trade is - as we point out - to a significant degree illicit, etc. Compared with other commodity markets such as copper, the market for coltan differs significantly!

${ }^{7}$ Notice that data refer to different units. This table represents our calculation method. UN COMTRADE refers to ores and concentrates of tantalum, niobium and vanadium without further specification. Implications will be discussed.

\begin{tabular}{llc}
\hline Unit & Used in Statistics & Factor \\
\hline $\begin{array}{l}\text { Gross mass (metric tons) Columbite-tantalite } \\
\text { (Coltan) }\end{array}$ & $\begin{array}{l}\text { Countries in the Great Lakes Region, USGS } \\
\text { Minerals Yearbook. Probably though not explici- }\end{array}$ \\
& $\begin{array}{l}\text { ty clarified: UN Expert Group, Global Witness, } \\
\text { Garrett / Mitchell }\end{array}$ \\
$\begin{array}{l}\text { Tantalum content, contained tantalum pen- } \\
\text { toxide }\left(\mathrm{Ta}_{2} \mathrm{O}_{5}\right)\end{array}$ & $\begin{array}{l}\text { Standard commodity, used in contracts. Parts of } \\
\text { International Trade statistics (UN COMTRA- }\end{array}$ \\
& DE), Chinese Import Statistics \\
Contained tantalum concentrate, Tantalite (Ta) & USGS Mineral Commodities & 1 \\
\hline
\end{tabular}
}


For quite a long time, Australia had dominated the world market with shares being in the order of $60 \%$ or even above. The production situation has changed significantly over the recent years. The largest producer, Australian-based Talison (formerly Sons of Gwalia) has suspended its production in late 2008 due to difficulties of financing necessary investments and market uncertainties during the financial crisis. USGS (2011) estimates the production amounts for 2009 as follows: Brazil (180t), Mozambique (110t), Rwanda (100t) Australia (80t), Canada (25t), other countries (170t, including Burundi, DRC (Kinshasa), Ethiopia, Somalia, Ugan$\mathrm{da}$, and Zimbabwe). Further supply may have been provided by others. ${ }^{8}$ It is evident that in 2009 Central Africa (including Mozambique) has been a major, if not the largest supplier of tantalum on the world market! This situation is very likely to continue in 2010-11.

\section{Figure 1: Tantalum, world mine production (unit: tantalum content, $\mathrm{Ta}_{2} \mathrm{O}_{5}$ ).}

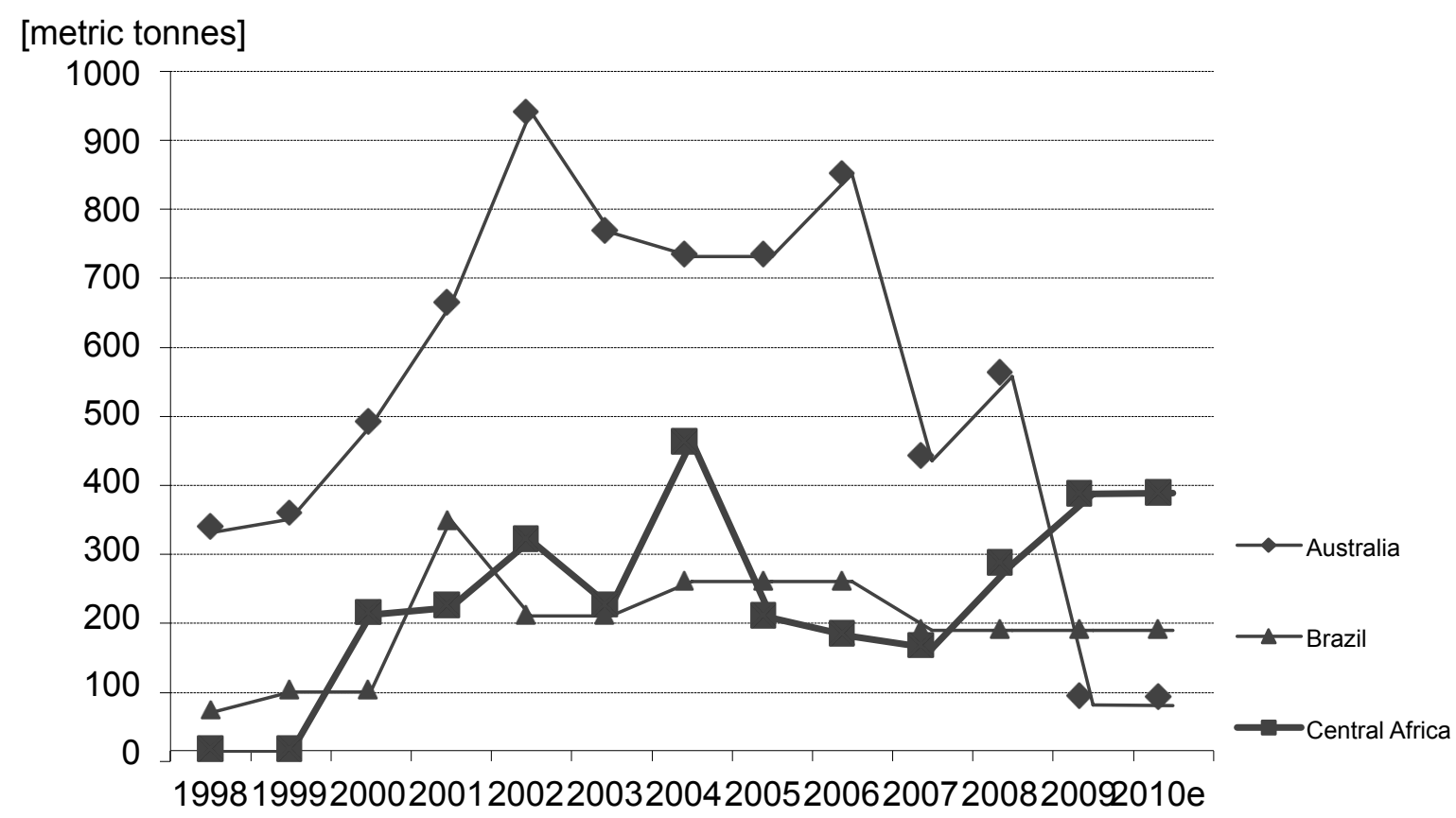

Sources: USGS (2011) and various other years of its tantalum report; data for 2010 preliminary.

Some supply is also provided by synthetic concentrates produced from tin slag, which are byproducts from tin smelting ( $7 \%$ in 2008, Roskill 2009: 12). Secondary production and recycling do not play a major role yet. Within industry, $20-25 \%$ of annual production inputs result from recycling activities done along production routes in attempts to reduce losses and minimize waste. Any approach to closing international material loops and to recycle tantalum from electronic goods and other products however barely exists. Reasons are related to

- Technology issues - the shares within products are tiny, challenges of pulverization during dismantling processes are huge, hence a need to develop new recycling technologies has been expressed ${ }^{9}$

Source: Roskill (2009: 6); USGS (2011: p. 52.13): Gross mass is mass of concentrate before metal is extracted, assumed to be one-third $\mathrm{Ta}_{2} \mathrm{O}_{5}$. Content is mass of metal produced; $\mathrm{Ta}_{2} \mathrm{O}_{5}$ is $81,897 \%$ tantalum. In general, $\mathrm{Ta}_{2} \mathrm{O}_{5}$ contents of ores vary from $0,1 \mathrm{~kg} / \mathrm{t}$ to $10 \mathrm{~kg} / \mathrm{t}$.

${ }^{8}$ Further estimations cover China (112 t), Russia (35 t), other Asian countries (57 t) as well as supply provided via tin slag (145 t) without changing the statement; we owe this information to Philip Schütte. See also Roskill (2009).

${ }^{9}$ Eurometaux's proposals for the EU's Raw Materials Initiative as of 11th June 2010, p. 49-50 (written with Institute for Applied Ecology). 
- Economic issues - establishing collection and dismantling systems requires an international approach implying high upfront transaction and investment costs while no regulation exists;

Thus, material leakage and dissipative losses are quite high.

Market demand for tantalum has been increasing over the last $10-15$ years. Some $60 \%$ of tantalum is being used for capacitors in electronic goods and devices such as mobile phones, pagers, PCs etc. (Roskill (2009: 110ff). The continued growth of the mobile phone sector in Africa, Asia, and other regions will continue to be a source of growth. In addition, tantalum carbide is used for high-tech cutters, in air and space technology, and for turbines. Future demand is expected to grow, with new applications in ICT, machinery, energy production turbines, energy storage, aircrafts and optical industry. Possible substitutes in those areas exist, such as niobium in carbides or rare earth elements for high temperature applications. But none of these possible substitutes performs as effectively as tantalum so far, they may pose other challenges, and rare earth elements are regarded as critical metals too. For these reasons, tantalum ranks in the upper right quadrant of the EU's Raw Material Initiative ${ }^{10}$ where the most critical minerals are listed; its economic importance is very high, the supply risk must be taken serious, and the environmental dimension should not be overlooked.

Thus, coltan mining in the DRC cannot be isolated from international markets and can hardly be focused on one application only (e.g. mobile phones). Research can transfer lessons from other conflict minerals, such as diamonds. However, coltan is not an end-product in itself and the production chain is complex. Thus, the specific characteristics of this material need to be considered in the design of any certification scheme (see below).

\section{Coltan mining in the DRC}

Due to specific geological conditions - deposits are too small to be amenable to large-scale industrial mining -, Coltan mining in eastern DRC is mainly done as artisanal and small-scale mining (ASM, Garrett 2008). ASM differs considerably by mineral and province in terms of how the sector is governed, how the economy and society are structured, and the form of the mining groups. The sector is dynamic in its proliferation, with new ASM sites springing up regularly, frequent power shifts and mineral-specific reconfigurations of actors and local informal governance regimes.

Employment is mainly for low-skilled local people. Estimations vary on the number of artisanal miners between 500.000 and 2 million in DRC. With an average of four to five dependents for each digger, the total number of persons whose livelihood depends on this activity could be as high as 8 to 10 million or up to $16 \%$ of the total population of DRC (World Bank 2008: Nest 2011: 17ff.). The majority of miners subsists on US\$ 1-5 per day, and is often locked in debt to local traders and strongmen. Small scale miners have no legal mineral rights under the Mine Law (adopted 2002); instead of tax or mining license they have to buy annually a digger card for 25 US $\$$ from provincial authorities. Many of the diggers cannot afford this amount, and at the same time government has no capacity to force the payment. Children are often employed too. Some mines operate on a barter economy, which makes it risky or impossible for miners to save and invest. Nevertheless, in many parts of the DRC, ASM remains the sole income opportunity. Given the lack of alternatives however, Garett and Lintzer (2010: 401) characterize ASM as the "safety net to support people and economies even under adverse circumstances".

\footnotetext{
${ }^{10}$ European Commission (2010): Critical raw materials for the EU. Report of the Ad-hoc Working Group on defining critical raw materials. See also: Annex V to the Report, pp. 188ff.

Accessible at: http://ec.europa.eu/enterprise/policies/raw- materials/documents/index_en.htm
} 
DRC has quite recently (June, 2011) adopted its first environmental legislation including, amongst other, environmental impact studies for mining activities (Republique Democratique du Congo, 2011). While big companies usually have knowledge and financial capacities to comply with the legislation and international standards, ASM activity in DRC normally doesn't follow even low environmental standards. ASM, for example, also takes place in the lowland sector of Kahuzi Biéga National Park, one of the last resorts of mountain gorillas worldwide. The national park is listed as World Heritage Site in Danger, UNESCO reports that only few areas are covered by patrols (UNESCO, 2008 and 2011). As indicated by a study on the mining sector in DRC (World Bank 2008), the polluting effects of this artisanal activity include possible decadence of unsafe mine tailings and waste dumps, water pollution caused by acid mine drainage, improper closure of pits and mines, dumping of toxic effluent into the water, mining waste, etc. Landscape alterations such as forest clearance and cutting of timber and firewood are serious and often irreversible, with secondary effects on local agriculture, fishery and forestry that is devastating if small scale farmers hire themselves out as diggers (Nest 2011: 49).

In addition to the environmental consequences directly and indirectly caused by mining, the presence of armed groups and their control over several areas can aggravate the destruction of natural habitats. In fact, the armed groups don't limit themselves to profit from the extraction of minerals, but they finance themselves through the illegal exploitation of other natural resources too (minerals such as gold, cassiterite, tungsten and other natural resources such as timber trade, meat, illegal fishing and poaching, UN 2010). Focusing regulation on one issue thus gives incentives to shifting illegitimate activities rather than abandoning them.

There is robust evidence on how rebel groups are profiting from the minerals extraction and trade. Of the 13 major mines, 12 are said to be controlled by armed groups (Nathan / Sarkar 2010: 22). The weakness of DRC's institutions and the lack of an effective and sufficiently paid national army, are responsible for the proliferation of military groups, which replace this vacuum with alternative forms of governance. ASM is often controlled by small, locallybased armed groups or militias, collectively called the mai mai. The larger armed units and the mai mai both "tax" the mines directly and indirectly extort money or minerals at the check-points they control. Especially two groups, the Congrès National pour la Défense du Peuple (CNDP), a political movement with a military wing called the Congolese National Army (CNA), and the Forces Démocratiques de Libération du Rwanda (FDLR) have been investigated by UN Expert Panels. CNDP presence is limited to few coltan mines. The Bibatama Coltan mine e.g. is owned by a national senator who seems to accept the presence of the CNDP and pays a price of $\$ 0.20 / \mathrm{kg}$ exported at checkpoints. FDLR, on the contrary, has been present in the two Kivus for at least 14 years. The group can count on a strong business network that enables the militia to receive the supplies needed, including weapons. The UN panel estimates that FDLR is reaping profits worth millions of dollars a year from trade of minerals in eastern DRC. For these relations they are described as "les grands commerçants" and they often involve Congolese civilians that are forced to act or trade on their behalf. More in general, the typologies of involvement of these armed groups in the mineral trade can vary, including taxation, payment of protection fees, commercial involvement in the mining activity and pillage. ${ }^{11}$ Worth noting, that these groups also profit from other minerals such as gold and cassiterite.

The recent UN report (S/2010/596) establishes evidence on the involvement of the Congolese national army. Congolese army units are competing among themselves for control over mineral-rich areas; they collude with armed groups in order to attack rival commanders, and they

\footnotetext{
${ }^{11}$ See OECD (2010: 20f), UN report 2010 S/2010/596, pp.48-49 and UN S/2008/773, paras 73 and 779 for a more detailed description.
} 
have gained control over large areas rich in natural resources in North and South Kivu provinces. In Walikale territory, the part of North Kivu richest in cassiterite (tin ore), control of the minerals trade was "awarded" to the CNDP to encourage it to integrate into the Congolese army, as agreed in an early-2009 peace deal. Though the formal army in the DRC is paid, the payment is just low, so the challenge is about the magnitude of payment and incentives for additional sources of income.

This situation of increasing involvement of armed groups in mineral trade and the difficulty of getting rid of it has been used as official justification by the Government of DRC for its temporary freeze in the mining activities of the provinces of South and North Kivu and Maniema on 11 September 2010 (UN 2010). The consequences of this action on production are still unknown. The UN claims that mining activity is still ongoing at night. It is sure that those who will be mostly affected are the people who depend on this activity for their living.

Main actors in coltan mining in the DRC are as follows (figure 2).It is thus not just a conflict over mining activities. Resource rents can be accrued throughout a number of subsequent transportation stages and intermediaries at local markets within the region. The number of actors involved (see graph) and the fact that official representatives and armed groups often cooperate make up for an intransparent situation. Even like-minded actors have difficulties to get evidence on whether any permission or certificate is legally correct and complies with basic laws. As a result, many actors benefit from the current situation, and there is hardly an incentive to change this from within: a self-perpetuating lock-in situation within a fragile state.

\section{Figure 2: The supply chain of coltan for electronics industry}

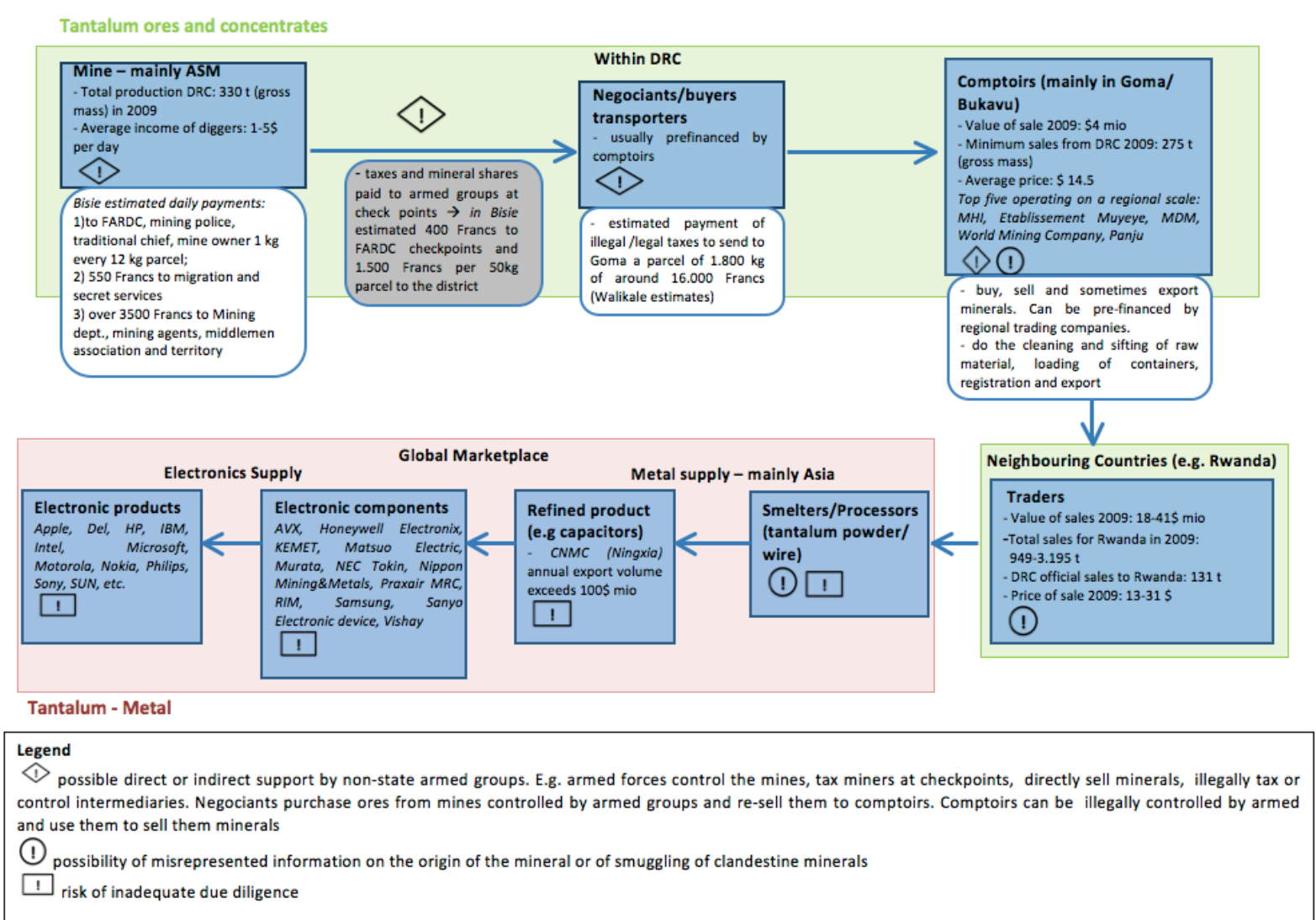

Source: Own compilation, OECD (2010), Resolve (2010), Garrett and Mitchell (2009), Global Witness (2009), TIC (2010), UN reports (2008, 2010), Enough! (2009). 


\section{Coltan and international trade: dimension and actors}

Tantalum materials are not openly traded; there is no stock market or spot market where prices could be compared. Purchase contracts are confidential between buyer and seller. Current data evidence reveals that Central Africa has become the major supplier for coltan / tantalum on world markets in 2009/10 - and possibly even earlier. However any estimation of the total amount of coltan produced in the DRC and traded internationally is limited by data availability, comparability and reliability as well as by difficulties of tracing illegal trade in Eastern Congo. Thus, tracing any illicit trade and estimating the real amount of coltan produced in and exported by DRC remains a central challenge.

The following part of our paper starts from the assumption that any illicit trade with coltan sooner or later enters the markets and is hence reflected in statistics downstream. Going beyond inconsistencies of DRC data, two possible gateways for such laundry mechanisms will be investigated: ${ }^{12}$

1. Neighbouring countries: they may declare exports that are not entirely covered by adding up domestic production and imports (and possible stockpiles).

2. Importing countries: especially huge economies may declare imports that are not equal to exports of that respective country. ${ }^{13}$

Our paper calculates coltan exports of DRC based on the information of those trading partners who reported to UN Comtrade ${ }^{14}$; this is compared with other available estimations (Roskill 2009, USGS 2011, UN Expert Report 2008, Global Witness 2009, Garrett/Mitchell 2009). We use mass units because they are not biased by monetary valuation and price volatilities. ${ }^{15}$ Due to the fact that not all countries report their trade, bilateral trade results have to be considered as minimum exports from DRC.

In addition, trade of coltan from DRC is estimated by analysing the trade flows of the neighbouring countries in the African Great Lake region, especially Rwanda, which have been mentioned as preferred trade routes of illicit trade with coltan and other minerals (e.g. Garrett/Johnson 2008; Garrett/Mitchell 2009; Global Witness 2009, 2010; UN Expert Panel 2008).

Available data give apparent evidence that DRC has been increasingly producing and exporting coltan especially since 2006 (see figure 3a and 3b). Trade data doesn't specify content and concentration of the ores and concentrates; but the results are in line with other studies referring to gross mass of tantalum / niobium production. USGS (2011: 52.13) shows an increasing production from 52t (2006) up to 267t (2007), 380t (2008) and 330t (2009, gross mass). While Roskill (2009) does not quantify tantalum production of DRC separately, Global Witness (2009) quoting official government statistics from North and South Kivu reveals that $428.4 \mathrm{t}$ of coltan (gross mass) were exported in 2007 and at least $270.79 \mathrm{t}$ in the first half of 2008. The UN Expert Report 2008 estimates that DRC produced and exported at least $393 \mathrm{t}$ in 2007 and $300 \mathrm{t}$ between January and July 2008. Finally, a study by Garrett and Mitchell (2009) sums up the official figures ${ }^{16}$ from North and South Kivu for 2007 and 2008 (total + December estimate) and adds to these data a $35 \%$ estimation based on calculations on transport volumes. The values obtained are $360 \mathrm{t}$ for 2007 and $517 \mathrm{t}$ for 2008 . These data dif-

\footnotetext{
${ }^{12}$ Potentially it might also be interesting to assess business reports since coltan / tanatalum is input to specialized capacitor production with few producers worldwide it might be possible to get evidence for inconsistencies. But the data availability in that area is too poor yet.

${ }^{13} \mathrm{We}$ refer, for example, to the comparison between exports figures from DRC and import figures from China.

${ }^{14}$ The DRC hasn't been reporting trade figures to international organisations since 1987.

${ }^{15}$ See e.g. Dittrich (2009) on the physical dimension of international trade.

${ }^{16}$ The sources of data are Division des Mines of North Kivu and the private sector federation of Bukavu
} 
fer by some 47\% (USGS vs. UN Expert Panel in 2007) and 36\% (USGS vs. Garret/Mitchell in 2008), and show clearly an upward production trend.

In 2009, bilateral trade data (see fn 7) indicates that DRC exports mount up to a minimum of $275 \mathrm{t}$ with a value of around 4 million US\$ - comparable to the combined production of Brazil and Australia in that year.

Figure 3a: Estimated production and aggregated trade of coltan ores of DR Congo, 1996 $-2009$

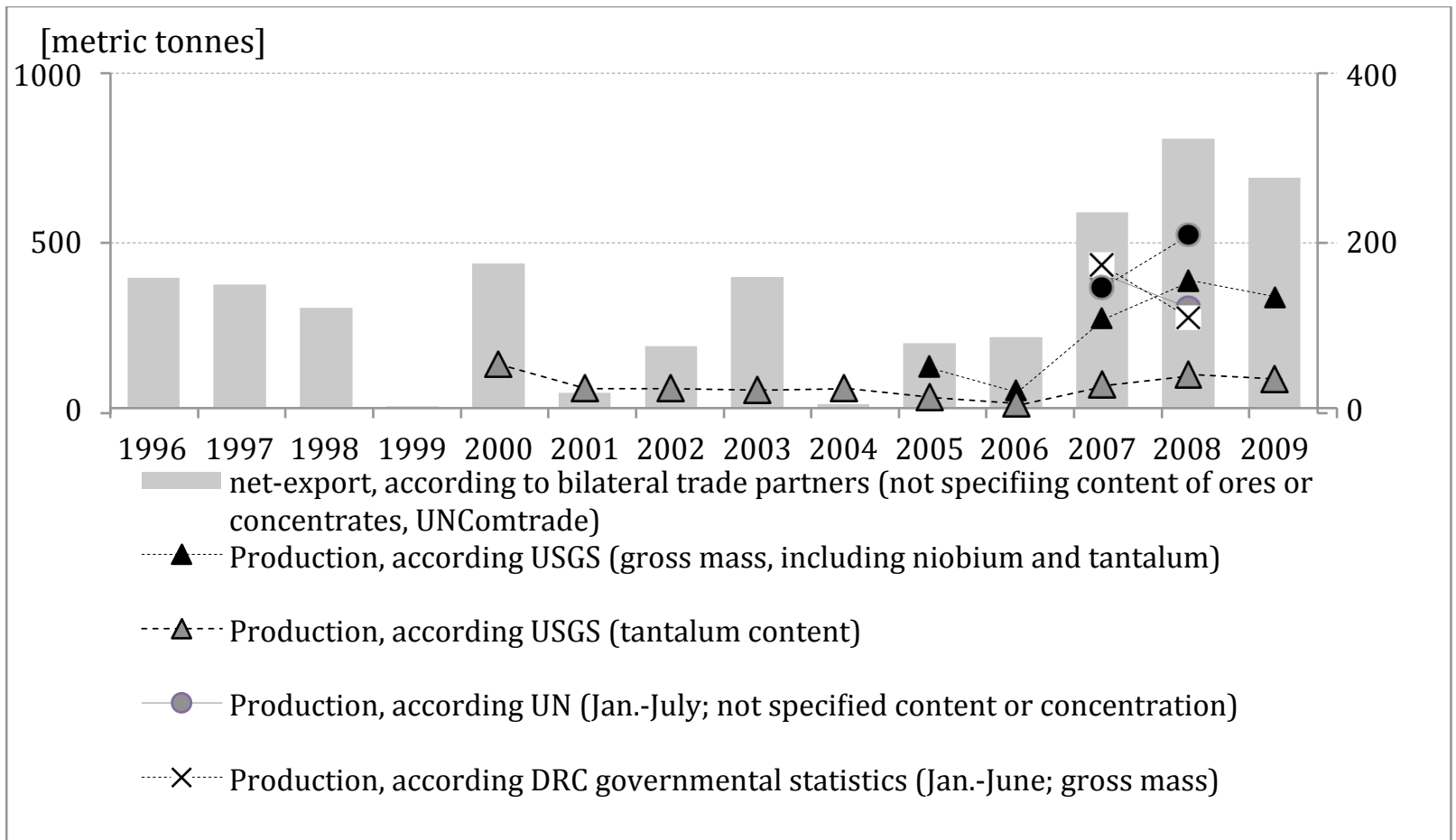

Sources: UNComtrade (here and in the following: SITC-3-28785; please note: the classification includes tantalum, niobium and vanadium; numbers don't specify content and concentration of ores and concentrates. In line with other sources we assume that DRC does not export vanadium ores and the share of niobium and tantalum is around 50 : 50); USGS (2011) and various years; gross mass is mass of concentrate before metal is extracted; UN Expert Report 2008 (2008 only Jan-July); Global Witness 2009 (2008 only first half); Garrett/Mitchell 2009. 
Figure 3b: trade of coltan ores of DR Congo by trading partners, 1996 - 2009

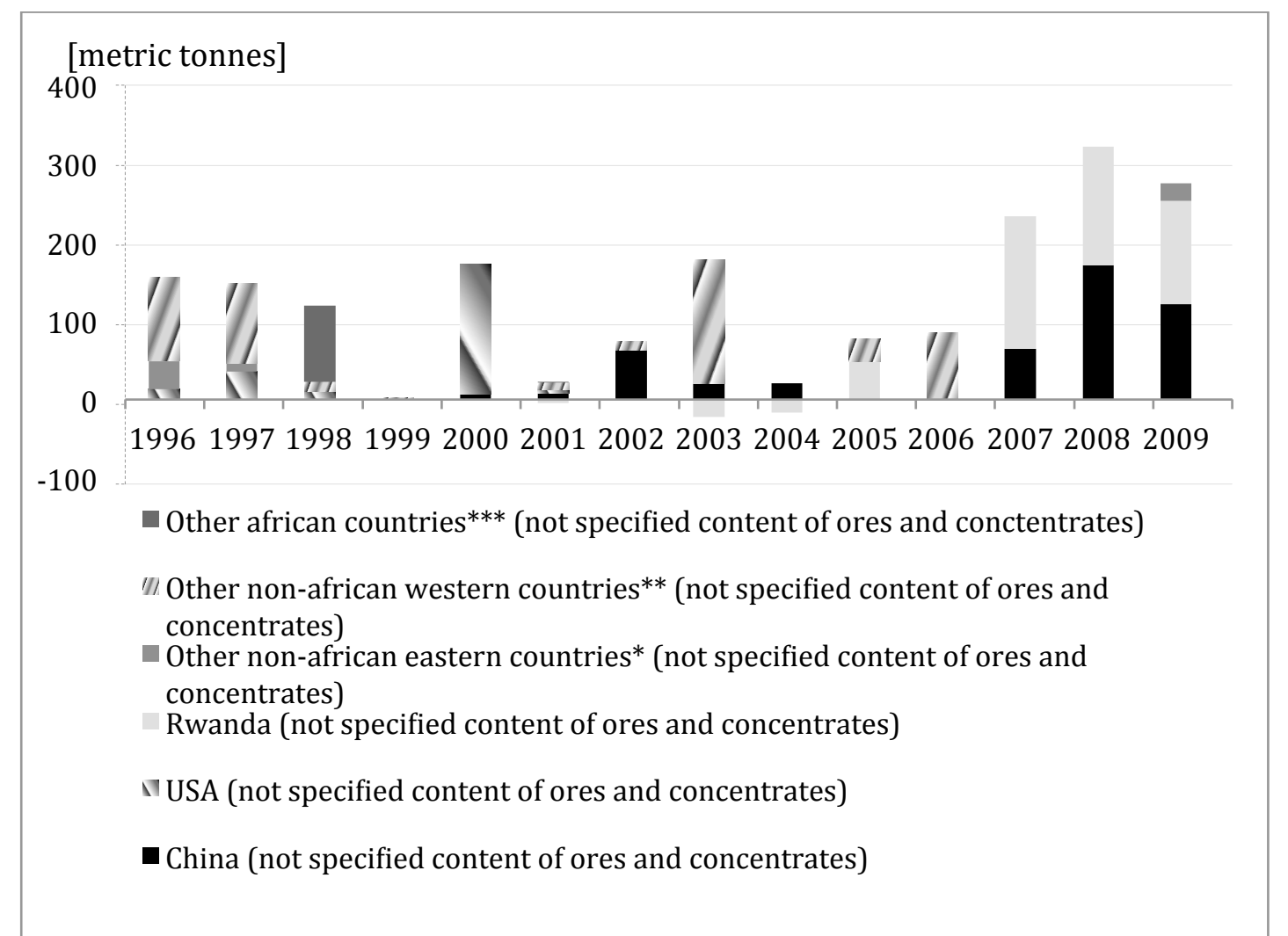

Sources: UNComtrade; *Singapore, Hong Kong, Japan, Rep. of Korea; **Brazil, Germany, Estonia, Belgium; ***South Africa, Uganda (each in order of relevance).

As mentioned above, Rwanda is deemed to be the preferred trade route for illegally traded minerals financing the conflict parties for several reasons. Besides geographical reasons, exports of tantalum concentrates aren't taxed in Rwanda while DRC has been taxing official mineral exports. Thus, trade via Rwanda is more profitable than legal exports via Kinshasa (Garrett/ Johnson 2008). According to Rwandan law, imported minerals could be declared as minerals produced in Rwanda if they are further processed in Rwanda and enhanced in value of about $30 \%$. Thus, coltan imported from DRC to Rwanda could be legally exported as coltan from Rwanda without separating whether it was imported legally or illegally. Global Witness (2010: 13) even goes as far as to name Rwanda a laundering centre in international trade.

Though Mozambique is according to USGS (2011) the most important producer of tantalum ores in Central Africa, ${ }^{17}$ Rwanda is the most important exporter of tantalum and niobium in Central Africa ${ }^{18}$ supplying around $75 \%$ of all exported ores and concentrates of these metals in 2009 according to trade statistics. A comparison of trade and production information for Rwanda shows remarkable inconsistencies ${ }^{19}$ (see figure 4). Obvious are high net-exports

\footnotetext{
${ }^{17}$ TIC (2010) refers to misreporting of production figures in Mozambique. Comparing Mozambique's trade data, our analysis is that relevant difference occurs in trade with USA; USA imports around $50-80 \mathrm{t}$ more according to its own trade data than according to Mozambique's trade information in $2007-2009$.

${ }^{18}$ Burundi, Central African Republic, DR Congo, Ethiopia, Kenya, Mozambique, Rwanda, Tanzania, Uganda Zambia, Zimbabwe. Note: none of these countries are mentioned in USGS as important producer of vanadium; therefore it can be assumed that data quantify tantalum and niobium ores and concentrates. Worldwide, Brazil is main supplier for niobium $(\approx 95 \%$ of the world market).

${ }^{19}$ Analyzing production and trade data of Mozambique, Kenya and Uganda also brings to light incoherencies which could be indicating (partly or fully) illicit trade from DRC but they are minor compared to Rwandan statistics.
} 
compared to very moderate production figures. However because of different definitions of tantalum ores and concentrates in UN Comtrade and USGS statistics (see fn 7), the mathematical difference should be interpreted with caution. Eye-catching is the rising gap between Rwanda's information on exports and the information given by the trading partners since 2006. According to Rwanda's sources, it imports $131 \mathrm{t}$ of tantalum and niobium ores from DRC in 2009 with a value of around \$ 1.1 million, and exports around $949 \mathrm{t}$ of tantalum with a value of around $\$ 18$ million. According to its trade partners, however, Rwanda's netexports of these ores and concentrates amount up to $3.195 \mathrm{t}$ with a value of $\$ 41$ million in 2009. The difference of a factor 3.3 in production and 2.3 in value is striking but the interpretation is not unambiguous. The data seems to indicate an increasing illicit trade since 2005 from Rwanda for an amount that could hardly be quantified exactly. ${ }^{20}$ However the differences could also be caused (partly) by double-counting and implausible data reported by importing countries $^{21}$, most importantly Chinese imports that dominate the figure.

Figure 4: Estimated coltan production and trade of Rwanda and Central African Countries

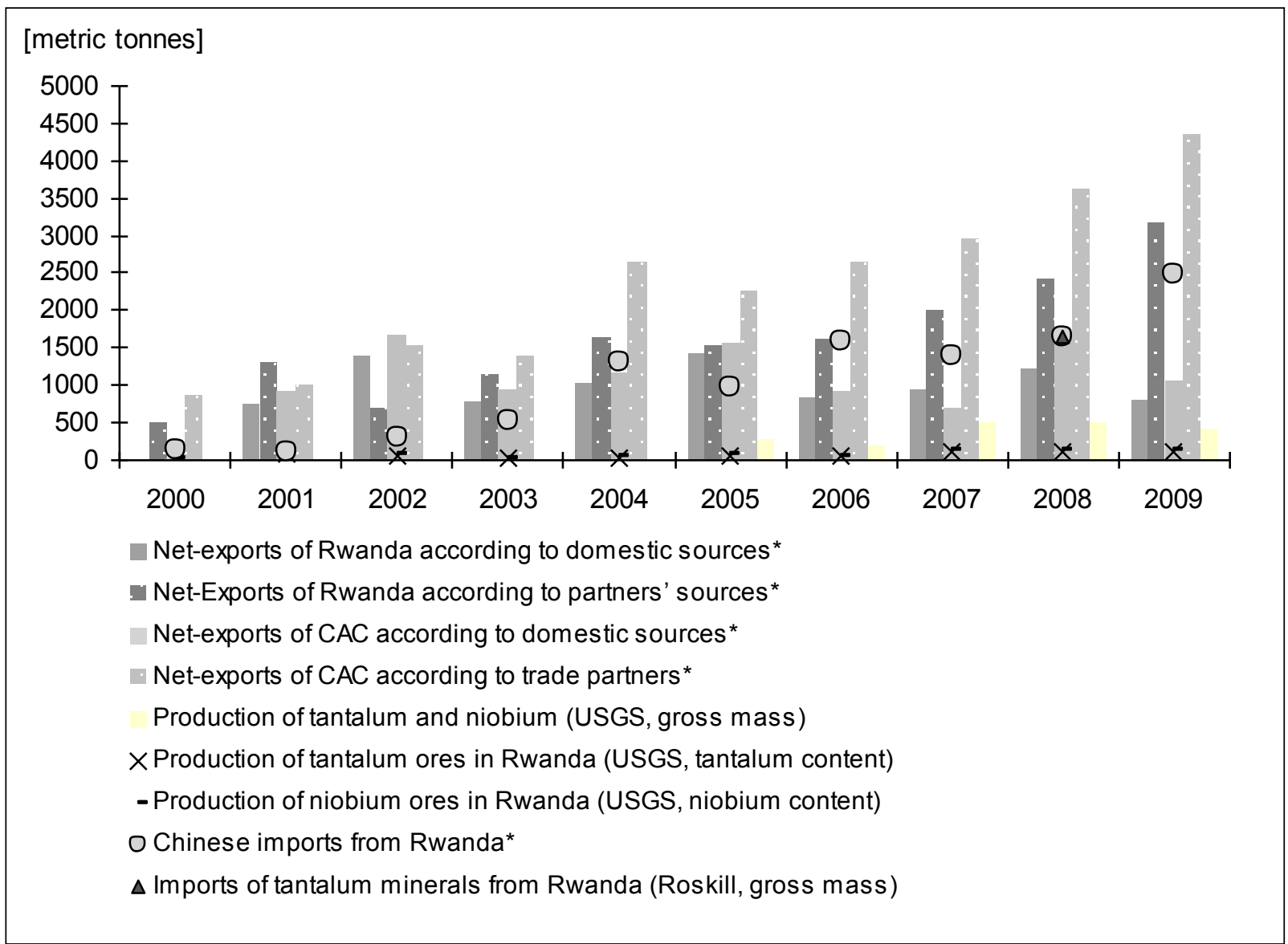

Sources: UNComtrade, USGS; *Unspecified contents of tantalum, niobium and vanadium ores and concentrates.

There is no doubt that a regional shift of trade pattern can be observed: during the nineties, western countries had been the dominant importers of coltan from DRC. Since 2000, Asian countries, most dominantly China, increasingly import coltan directly from DRC. This goes in line with the overall increase of trade between African countries on the one hand and on the other hand China and other developing countries who are investing predominantly in resource

\footnotetext{
${ }^{20}$ See also Global Witness (2010: 13) on Rwanda and cassiterite from DRC.

${ }^{21}$ Differences in monetary values may also (partly) be caused by different use of INCOTERMS: cif (=cost, Insurance freight) values are often used for imports, fob (free on board) values are often used for exports. However in our view this cannot capture such differences.
} 
rich African countries (UNCTAD, 2010). According to data from the Congolese Ministry of mines collected by the NGO Global Witness (2010), the coltan imported by China constitutes $60 \%$ of the North and South Kivu's production. In 2009, China has purchased $121 \mathrm{t}$ of coltan (most probably: gross mass) with a value of around 2.6 million US\$ directly from DRC.

China is also by far the most important importer of tantalum produced in the Central African region. Since 2000, China's imports of tantalum and niobium ores from this region rose from $435 \mathrm{t}$ or 11.3 million US\$ to $3.154 \mathrm{t}$ with a value of 36.3 million US\$ in 2009. Direct imports from DRC are minor compared to other suppliers, among which the most relevant is Rwanda (see figure 5). In physical terms, China imported around $73 \%$ of all exported tantalum and niobium ores of the region (assuming that vanadium is rather negligible).

Roskill (2009: 105) reports 1,656 t of imported tantalum minerals from Rwanda in 2008 roughly 4,6 times the amount of Rwanda's production according to USGS (2011: 52.13, $120 \mathrm{t}$ ta content $\approx 490 \mathrm{t}$ gross mass). Roskill's numbers, based on private sector information, lies between Rwanda's information of its net-exports of ores and concentrates of tantalum as well as niobium and information of trading partners about its net-imports of these ores and concentrates from Rwanda. If one assumes an import from DRC in the order of $131 \mathrm{t}$ (data for 2008, including ca. $50 \%$ niobium ores $\approx 262 \mathrm{t}$ gross mass), the difference is significant. Their report also estimates main smuggling activities via Rwanda. With all uncertainties involved, one may thus estimate that $914 \mathrm{t}$ of these minerals might stem from illicit trade - a share of some $55 \%$.

Compared to other importers like Hong Kong or Singapore, China's imports have a significantly lower price ( $\$ 11.33$ per kilogram tantalum and niobium ore versus $\$ 24.26$ paid by other Asian importers). In this context, it is also interesting to note that prices for coltan from DRC have been increasing since 2007 while prices have been rather decreasing for exports from the other countries in this region. Prices for coltan imported from Rwanda had been constantly low. In 2009 China purchased coltan for even less than \$ 8 per kilogram according to its trade report while coltan exports from Rwanda costs between $\$ 13$ and 31 per kilogram on a monthly average, depending on tantalum grades ${ }^{22}$. Roskill (2009: 148) reports that the average price of China's imports from Rwanda has been $2-2.7$ times lower than the import price of Australian tantalite. In the first half of 2009 it was 3.7 times lower. Not neglecting different qualities (see $\mathrm{fn} 7$, these enormous differences can be assumed as key reasons for the strong position of Rwandaas a trade hub, the shifting of capacitor manufacturing to China, and the currently miserable situation of the conventional supply chain of tantalum. And, indeed, it fuels illegal and criminal activities of all kinds.

Following the estimation of around 900 tonnes illicit trade in the most recent year and assuming similar price ranges for coltan from DRC and Rwanda results in a loss of potential income in the order of between $\$ 12$ and 28 million for DRC in that year. ${ }^{23}$ This is a significant amount in a country, which ranges at the bottom of development rankings (HDI position 187 out of 187, UNDP 2011). On top of that one would also have to add loss of revenues from other illegal mineral exports.

The typical supply chain of coltan produced in DRC and sold by illegitimate means thus looks as follows: it is exported via Rwanda or other Central African Countries, and is bought by Chinese processors. These processors are often smaller companies who do not have pressure to disclose information or to report. They, in turn, produce and export downstream products such as K-salt used to make capacitor-grade powder. Those products do enter the global market while their origins are obscured.

\footnotetext{
${ }^{22}$ Personal information by Philip Schütte, BGR.

${ }^{23}$ See also Nest (2011: 94) and the calculation of \$ 11,8 million in 2008 as estimated profit for armed groups.
} 
Figure 5: China's imports of tantalum and niobium from selected African countries

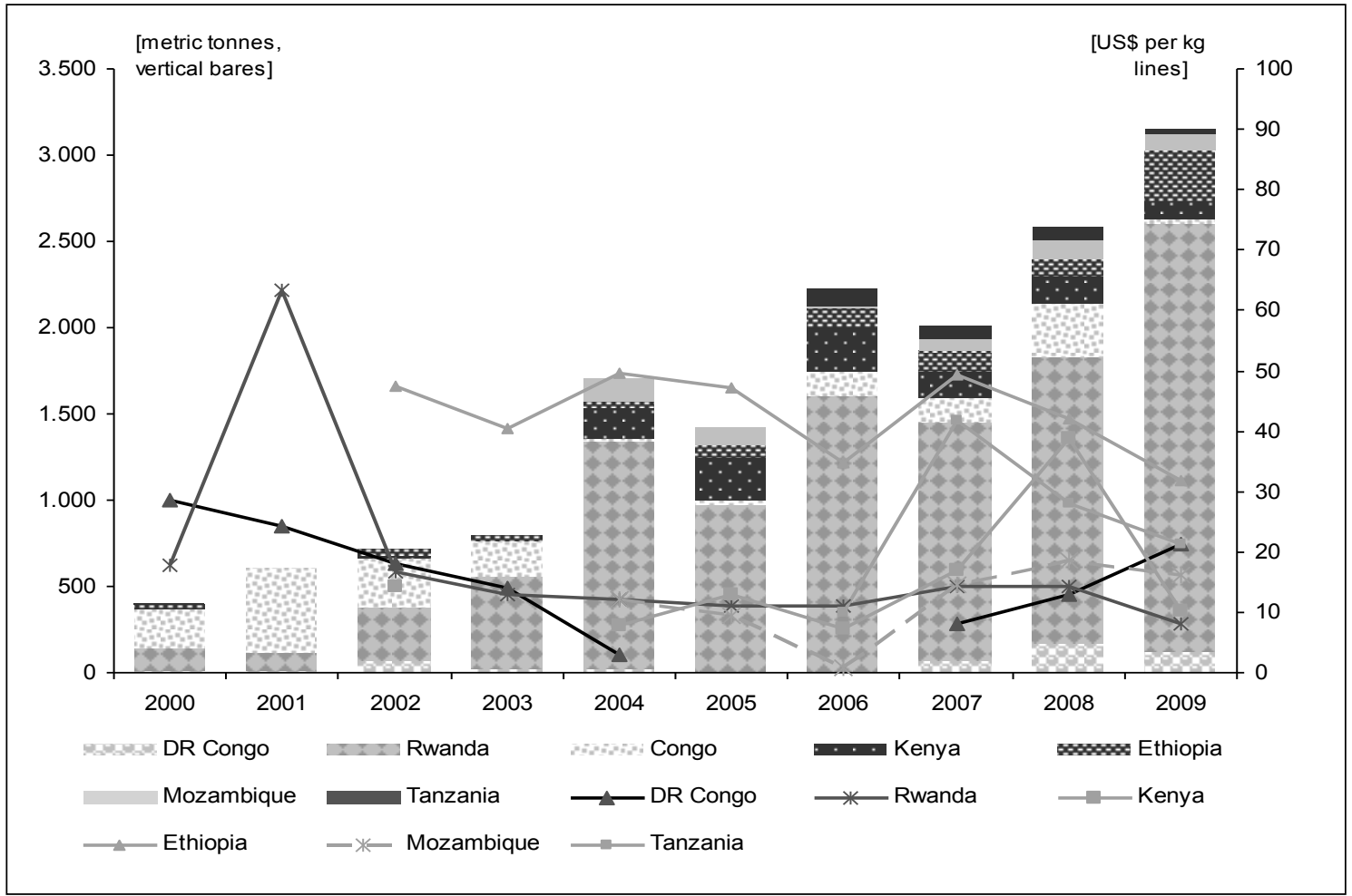

Source: UN Comtrade (SITC-3-28785)

According to the official statistics reported by Global Witness (2010), three Chinese companies figure among the main importers of coltan from the Kivus in 2009: Fogng Jiata Metals, Star 2000 Services and Unilink Trading Hong Kong. The latest UN report (2010) doesn't consider these companies as involved in the minerals trade from areas controlled by armed groups, but it is unclear how the Chinese government intends to meet any responsibilities in such trade.

The case of CNMC Ningxia Orient Nonferrous Metal Group seems illustrative for these concerns. The state-owned enterprise is one of the world's top three smelters and producers of tantalum. The tantalum it produces is used by the largest capacitor manufacturers such as the US based AVX, that in turn supply electronics to companies such as Dell, Intel and RIM ('Blackberry') and Hewlett-Packard. Although the company claims to have transparent sourcing practices, Global Witness (2010) has raised concerns that the K-salt ${ }^{24}$ that the company uses to produce tantalum and that it claims to come from refineries in China, can be used to cover the Congolese origin of the tantalum they use. Nathan / Sarkar (2010: 23) claim that Ningxia continues to import coltan from DRC despite all concerns. Ningxia has not responded to a questionnaire that was done by Resolve (2010: 39) in a attempt to address supply chain challenges for electronics industry and their use of critical metals. ${ }^{25}$ It is also interesting to see that capacitor production in China and exports thereof have been increasing rapidly over the previous few years, meaning that any supply chain management with certification rests more and more upon the credibility of China.

\footnotetext{
${ }^{24} \mathrm{~K}$-salt is tantalum ore that has been chemically refined to make the compound called potassium tantalum fluoride

${ }^{25}$ According to Resolve (2010: 39), all major producers of electronic goods responded on tantalum (Apple, Dell, HP, IBM, and others), roughly half of the component manufacturers, only one of the processors (Cabot), and none of the actors involved in earlier stages (except Talison, the Australian mining company). The study was done on behalf of the Global e-Sustainability Initiative (GeSI) and the Electronic Industry Citizenship Coalition (EICC).
} 


\section{Lessons for any certification scheme and better resource governance}

Our analysis reveals inconsistencies in tantalum data and indicates a remarkable scope for hiding illicit trade. Both the neighboring countries and the Chinese gateway show a dimension according to which the total amount of coltan traded may outweigh the official DRC production, possibly by a factor of three. This magnitude is in line with UN expert group estimations that have been done domestically in the DRC in 2008 and 2010 and trade data. To illustrate this: if one assumes illegitimite imports from DRC/Rwanda to China in the dimension of 914 $\mathrm{t}$ (gross weight 2008, see above, not to mention other illicit routes) and a market price of $\$ 87$ $/ \mathrm{kg} \mathrm{Ta} \mathrm{O}_{5}$, the value of such illicit trade of tantalum comes close to $\$ 27$ million annually, ${ }^{26}$ roughly one fifth of the estimated world market volume for tantalum production. Though these gateways are merely a first indication and not a robust result yet, the result gives an impression of the potential revenues from coltan mining in DRC if coltan would be traded transparently and legally.

Production and trade data on minerals involved in armed conflicts are needed in an internationally comparable scheme with open access, supported by reliable national and regional reporting requirements. This should include detailed information about local origin, prices and ore concentrations. In the short term, it could be organized by an international group of experts in charge with collecting, comparing and evaluating available data, including data on international trade. ${ }^{27}$ In the medium term, it would be favorable to harmonize international statistical methods and classifications, and to develop full material flow accounts including secondary production and recycling as well as financial flows.

Despite all uncertainties regarding data, however, analysis can draw useful lessons for any certification scheme. The following three governance challenges become obvious:

Firstly, Central Africa including the DRC and Mozambique is now the largest supplier of col$\tan$ / tantalum on world markets. Our short analysis of the DRC reaffirms that major actors in the region cooperate in their efforts to profit from mining and trading coltan. The conflict structure is dominated by rent-seeking activities of a number of actors over all stages of the supply chain until it enters official markets, not just by fighting over mining licences. The involvement of DRC officials, the ability to earn incomes higher than average as well as the desperate situation of the local population, triggered by high world market demand and no transparency requirements, favor a rather perverse stability of such situation. Any certification scheme thus should take into account the ability of all actors involved to mix legal mining products with others along the first stages of the supply chain.

Secondly, coltan (tantalum) has interesting characteristics for a number of technology applications. Focusing on one application (e.g. mobile phones) may raise awareness but bears the risks of shifting production patterns to other technology areas where public attention is comparatively low. In addition, focusing on a limited number of conflict minerals gives incentives for shifting illegitimate activities to other profitable minerals. The scope thus should cover all applications and all commodities from conflict regions.

Thirdly, the involvement of China, other Asian countries and production located there lead to international governance challenges while transparency is poor. The large number of small producers for a number of tantalum products such as K-salt and tantalum powder makes it fairly difficult to establish a reliable certification scheme. Moreover, the international dimension adds un-intended negative effects to certification schemes: if like-minded producers

\footnotetext{
${ }^{26}$ Calculated as follows: 914 (difference between imports acc. to Roskill 2008 and exports) : 3 (weight factor for Ta2O5) x 87,000 (\$ acc. to Popp, USGS 2011)

${ }^{27}$ Indeed it should include the data provided from recent efforts such as ICGLR certification and initiatives that might follow the implementation of the Dodd-Frank Act and the European Commission's proposals (see annex).
} 
manage to establish a sustainable supply chain management for a number of commodities (however difficult this may be!), their competitors and other value chains will benefit. With growing markets in Africa and Asia that do not have to comply with any certification in the US or in the EU this is a real risk. Economics supports such argument: a split demand results in a split price and split awareness, i.e. higher prices for those concerned and lower prices for those who do not care. Probably, the conflict situation wouldn't change much!

Governance challenges for certification thus relate to feasibility and reliability, to the scope, and to the international dimension. Above all, one should conclude that certification efforts should be accompanied be profound reforms in governance.

A two track approach of pilots on the region and capacitor-based certification may yield results. Since capacitor manufacturers consume roughly half of the tantalum world-wide and have a strong position in the supply chain, more attention should be focused here. The regional certification scheme developed by the ICGLR (International Conference of the Great Lakes Region) is a useful initiative in that regard. The mechanism, which had been formally adopted by the ICGLR heads of state, covers cassiterite, coltan, wolframite and gold and aims at achieving compatibility with other initiatives, such as ITSCi (Initiative of the Tin Smelting Capacitor Industry), GeSI (Global electronics Sustainability Initiative) and EICC (Electronic Industry Citizenship Coalition). Its main elements are chain of custody tracking from mine to export at country level, ${ }^{28}$ regional tracking of mineral flows through the creation of a database on their purchases, independent audits on all actors in the supply chain and a monitoring of the whole mineral chain by a Mineral Chain Auditor (Blore and Smillie, 2011). Compliance with certification schemes and data disclosure in their business reports is a key; third party audits, as suggested by OECD (2010), will improve reliability. Public offerings at regional stock exchanges may be options for the future. In particular it would help in the establishment of an international comprehensive monitoring mechanism and any enforcement.

These certification initiatives are taking advantage of the Kimberley Process for the certification of diamonds. Important lessons cover the purpose, administrative and operational aspects (Blore and Smillie, 2011). ${ }^{29}$ Following Haufler (2010) the elements of establishing inclusive and relatively strong institutions can be seen as key elements for success as well as market leverage in industrialized countries. The conclusion indeed is that administrative capacity building in the region with independent auditing will be a key to establish reliable evidence and to fight corruption. However, coltan differs from diamonds because

1. The number of actors involved upstream and their ability to mix illegitimate sources with legal ones during the first stages of the supply chain are huge; centralizing traders and monitoring $100 \%$ of their operations should be useful;

2. The security situation in the region remains fragile;

3. The production chain downstream is much more complex and entirely globalized, with Chinese companies being in the largest position;

4. Tantalum is not an end-product in itself, many companies are unaware yet whether it is a component in one of their products, and consumers have difficulties to realize it either.

\footnotetext{
${ }^{28}$ This aspect includes the emission of a regional certificate to ensure that mineral don't originate from conflict areas or are not illegally transferred among countries.

${ }^{29}$ Concerning the purpose, the system needs a flexible approach and objectives should also aim at incorporating longer-term goals of governance, development and ethical practices. As for the administrative aspects, the system should cover the whole supply chain, ensure transparency and inclusive decision-making, and include a strong administrative structure to manage it. Finally, operational aspects include ensuring that production sites are free from militia/armed forces, databases on production-exports of minerals, independent third party monitoring and follow up of problems, credible sanctions for defectors (Blore and Smillie, 2010).
} 
Thus a better coordination among international approaches to promote legal mineral trade is at stake. Table 1 (see Annex) reports relevant initiatives. Attempts to promote transparency should generally be supported because they have positive side-effects on markets and against corruption; however better coordination and harmonisation of data is a key to minimize overlaps and unproductive information overflow. International initiatives like the Extractive Industries Transparency Initiative (EITI) coincide with legislation such as the Dodd-Frank Act in the $\mathrm{USA}^{30}$ and the proposals of the European Commission to introduce transparency and accountability obligations for large public and not-public companies in the extractive and forestry sectors. The two legal initiatives may also have triggered the recent statement by the Congolese government to require, all organisations and individuals involved in the mining, transportation, sale, processing and export of the four conflict minerals" to introduce due diligence practices along their value chain (Global Witness, 11 th October 2011). ${ }^{31}$

This proves that voluntary efforts should be supported by international law to promote transparency, certification and accountability against corruption and in favour of sustainability. Following a suggestion made by Collier and Venables (2010: 15), the anti-bribery legislation that the OECD now requires of its membership could be a requirement of WTO membership - a compliance issue for China and elsewhere. In the long run, an international agreement on sustainable resource management might also be an option (Bleischwitz 2009).

A two track approach of pilots on the region and capacitor-based certification as outlined above should also be accompanied by better governance at both the national and regional level. As Mitchell and Garrett (2010) claim the general conditions and social sector reforms in Eastern DRC are urgent preconditions for any progress. As regards to prices and taxation, most researchers share the impression that the current systems neither capture negative externalities nor do they promote regional sustainable development. A general assessment and review of the DRC tax system with emphasis on simplification, transparency and accountability as well as raw material taxation at the extraction point would not only generate revenues but also give financing opportunities and incentives for value adding activities in the region (Garrett/ Mitchell/ Lintzer 2010). However tax competition with neighbouring countries (e.g. Rwanda) should be minimized via agreements - the EU offers a lot of practical guidance on how coordination can work. Such taxation also helps to establishing an appropriate legal order and could give more social security to mining workers and along the regional supply chain.

Ensuring that the profit from the mining sector trickles down to the local population with value creating activities may benefit from the establishment of an independent and accountable resource management fund. A regional resource fund where money of different donors and actors involved (public and private) can be pooled, could help ensuring better coordination among different actions, better allocation of investments and better division of the tasks. In addition, an improved and effective mining law that could be implemented with international support until the actual resource conflict is solved should be considered. ${ }^{32}$

UNCTAD $(2008,2010)$ suggests linking revenues of rising commodity prices strategically to developing goals such as infrastructure, education, health care or economic diversification, using even bilateral trade agreements in this context, e.g. by exporting raw materials for the construction of infrastructure. This could mean that the DRC extends the existing formal trade with China and other countries using their interest in coltan and other raw materials in order

\footnotetext{
${ }^{30}$ In November 2011 a Public-Private Alliance for Responsible Minerals Trade has been launched in the US to support the implementation of the Dodd-Frank Act

${ }^{31}$ Companies or individuals not complying within 45 days will be imposed administrative sanctions e.g. withdrawal of business licenses (Global Witness, 11th October 2011).

${ }^{32}$ Satellite fotos in military quality of the conflict areas can be useful in that regard. Garrett and Lintzer (2010) give arguments why the national government should further retire from extraction activities. Discussing the role of the UN as well as legal frameworks is beyond the scope of this paper.
} 
to finance governmental presence and (re-) build public infrastructure and improve processing capacities in its eastern parts. Further analysis may also shed light on the role of a development state and implications for any sustainable growth to contest the theory of a resource curse in this region (Collier / Goderis 2007; Gylfason 2009; World Bank 2008).

\section{Conclusions}

Our analysis of international trade statistics reveals a significant amount of illicit coltan in the order of some $20 \%$ on world markets (2009/10). At the heart of any solution should be the insight that markets need transparency and appropriate prices - safeguarded by proper institutions - to function properly. Illicit trade, intransparency and corruption are to be seen as major risks for the local population and for business. Market failures are likely to have substantial costs, in particular for a region like eastern DRC, but also for the market itself.

However a common interest for comprehensive solutions exists and stems from the critical need for such metals both in high-tech industries as well as in most countries. Australian mining company Talison is ready to re-enter the market as soon as current uncertainties will be reduced. Thus our estimation that current efforts to establish certification may have the unwanted side-effect of negative impacts in the eastern DRC should also lead to support for better governance in the region and in markets for minerals. Chinese companies, and in particular state-owned enterprises, should accept their responsibility to perform supply chain due diligence. Efforts to promote Corporate Social Responsibility (CSR) and the Global Reporting Initiative (GRI) with its focal point China may help to level the playing field. ${ }^{33}$

Further analysis will also have to develop governance mechanisms to turn illicit trade in minerals into opportunities for sustainable development. This will not only require harmonized data and monitoring, but also capacity building initiatives and enforcement systems for the main stakeholders as well as better institutions such as resource taxation systems. As expressed above, new international legal and economic mechanisms should be established. In that regard, the current barriers and deficits might be removed by international incentives for re-use and recycling: material stewardship is an encouraging concept where capacitor producers currently are key business actors. They should be part of a future international covenant for the recycling of critical metals that involves in particular electronics industry (Wilts / Bleischwitz 2011). Aim in this context is to increase industrial recycling, to collect more consumer goods and to establish recycling facilities internationally. Such covenant is well in line with high prices for primary resources as well as with fair trade.

This is, of course, an agenda that goes beyond the scope of our case study. Having said this however the authors also wish to express the view that bans are a less desirable option because they would result in further economic hardship for the Congolese people. Putting the raw material conflict issue in the framework of sustainable resource management and international governance for trade in natural resources probably is a better way forward.

\section{References}

BGR (Bundesanstalt für Geowissenschaften und Rohstoffe / Federal Institute for Geosciences and Natural Resources) (2011): Coltan : Herkunftsnachweis von Columbit-Tantaliterzen. http://www.bgr.bund.de/cln_145/nn_335232/DE/Themen/Min_rohstoffe/Projekte/RohstoffForschung/LF_Herkunftsnachweis__COLTAN.html [January 12th, 2011]

Besada, H. / Hannan, U. (2007): Dimensions of State Fragility: A Review of the Social Science Literature, CIGI Working Paper No.33, November

\footnotetext{
${ }^{33}$ See e.g. the reporting requirements for mining companies at: www.globalreporting.org and e.g. www.csreurope.org for efforts to promote Corporate Social Responsibility.
} 
Bleischwitz, R. et al. (2009): Outline of a resource policy and its economic dimension, in: Bringezu, S. / Bleischwitz, R. (Eds): Sustainable Resource Management. Trends, Visions and Policies for Europe and the World, Greenleaf Publisher, pp. 216-296.

Blore, S. / Smille, I. (2011): Taming the Resource Course: Implementing the ICGLR Certification Mechanism for Conflict-prone Minerals, Partnership Africa Canada, March

Brown, G. / Stewart F. (2009): Fragile States, CRISE Working Paper No. 51, January

Bringezu, S. / Bleischwitz, R. (2009): Sustainable Resource Management. Trends, Visions and Policies for Europe and the World, Greenleaf Publisher.

Collier, P. / Goderis, B. (2007): Commodity Prices, Growth, and the Natural Resource Curse: Reconciling a Conundrum, University of Oxford.

Collier, P. / Venables, A.J. (2010): International rules for trade in natural resources, WTO Staff Working Paper ERSD-2010-06.

Dittrich, M. (2009): The physical dimension of international trade 1962-2005: empirical findings and tentative conclusions, in: Bleischwitz, R. / Welfens, P. / Zhang, ZX. (Eds.) (2009): Sustainable Growth and Resource Productivity - Economic and Global Policy Issues, Greenleaf Publisher, pp. 85-98

European Commission (2011): Proposal for a Directive of the European Parliament and of the Council amending Directive 2004/109/EC on the harmonization of transparency requirements in relation to information about issuers whose securities are admitted to trading on a regulated market and Commission Directive 2007/14/EC. COM(2011) 683 final. 25 October 2011

European Commission (2011): Proposal for a Directive of the European Parliament and of the Council on the annual financial statements, consolidated financial statements and related reports of certain types of undertakings. $\operatorname{COM(2011)~} 684$ final. 25 October 2011

Garrett, N./ Mitchell, H. / Lintzer, M. (2010): Promoting Legal Mineral Trade in Africa's great Lakes Region, Resource Consulting Services London.

Garrett, N./ Mitchell, H./ Tromme, M. / Lintzer, M. (2010): Certified Trading Chains - Pilot Project Rwanda, Resource Consulting Services London.

Garrett, N. / Lintzer, M. (2010): Can Katanga's mining sector drive growth and development in the DRC? Journal of Eastern African Studies, 4 (3), p. 400-424.

Garrett, N. / Mitchell, H. (2009): Trading Conflict for Development, DFID, LSE, CRG.

Garrett, N. / Johnson, D. (2008): Wie Deutschland konfliktfreien Rohstoffhandel fördern will. Die Tageszeitung, 5./6. July, p. 4-5.

Global Witness (2009): Faced with a gun, what can you do? July 2009

Global Witness (2010): The Hill Belongs to Them. December 2010

Global Witness (2011): Congo government requires domestic minerals sector to source responsibly. 11 October 2011

Gylfason, T. (2009): Development and growth in mineral-rich countries, in: Bleischwitz, R. / Welfens, P. / Zhang, ZX. (Eds.) (2009): Sustainable Growth and Resource Productivity - Economic and Global Policy Issues, Greenleaf Publisher, pp. 42-84

Haufler, V. (2010): The Kimberley process certification scheme: an innovation in global governance and conflict prevention, in: Journal of Business Ethics 89, pp. $403-416$.

Nathan, D. / Sakar, S. (2010): Blood on Your Mobile? In: EPW (Economic \& Political Weekly), October 23, Vol. XIV, No 43, pp. $22-24$

Nest, M. (2011): Coltan, Polity Press.

OECD (2010): OECD Due Diligence Guidance for Responsible Supply Chains of Minerals from ConflictAffected and High-Risk Areas, Paris.

Revenue Watch (2011): Disclosure Rules: U.S. and EU Standards. 28 October 2011

Republique Democratique du Congo, Assemblee Nationale - Senat, Commission Mixte Paritaire (2011): Proposition de Loi Portant pricipes Fondamentaux relatives a la Protection de L'Environnement. Kinshasa/Palais du people. Adopted as Loi no 11/009 du 09 juillet 2001. 
Resolve (2010): Tracing a Path Forward: A Study of the Challenges of the Supply Chain for Target Metals Used in Electronics, prepared by Jen Peyser, Washington DC (www.resolv.org).

Roskill (2009): The economics of tantalum, $10^{\text {th }}$ edition, London (www.roskill.com).

TIC - Tantalum-Niobium International Study Center (2010): Bulletin n. 144, ISSN 1019-20296, December 2010

UN Comtrade, United Nations Commodity Trade Statistics Database, different years. http://comtrade.un.org/ [January $12^{\text {th }}, 2011$ ]

United Nations Development Programm (UNDP) (2011): Human Development Report 2011: Sustainability and Equity: A Better Future for All. New York.

Unite Nations Environment Programm (UNEP) (2011): The Democratic Republic of the Congo. Post-Conflict Environmental Assessment. Synthesis for Policy Makers. Nairobi.

United Nations Educational, Scientific and Cultural Organization (UNESCO) (2008): Convention Concerning the Protection of the World Cultural and Natural Heritage. WHC-08/32.COM/7A, 22 May 2008 http://whc.unesco.org/archive/2008/whc08-32com-7Ae.pdf [November, 30th, 2011]

United Nations Educational, Scientific and Cultural Organization (UNESCO) (2011): Convention Concerning the Protection of the World Cultural and Natural Heritage. WHC-11/35.COM/20, 7 July 2011

UN Interagency Framework Team for Preventive Action (2010): Extractive Industries and Conflict, Guidance Note for Practitioners, Draft 2010.

United Nations Security Council (2010): Report S/2010/596, Final report of the Group of Experts on the DRC, 29 November 2010 ,

United Nations Security Council (2008): Report S/2008/773, Final report of the Group of Experts on the Democratic Republic of the Congo, 12 December 2008.

USGS, United Nations States Geological Survey, different years. Minerals Information Niobium (Columbium) and Tantalum Statistics and Information.

http://minerals.usgs.gov/minerals/pubs/commodity/niobium/ [January $\left.12^{\text {th }}, 2011\right]$.

USGS (2011): Niobium (Columbium) and Tantalum, by John F. Papp, 2009 Minerals Yearbook.

Wilts, H. / Bleischwitz, R. (2011): Ein Covenant zur Schließung internationaler Stoffkreisläufe im Bereich Altautorecycling, MaRess Teilstudie AS 3.2; http://ressourcen.wupperinst.org/?id=271. a short English version (15 pp.) is availabe on demand.

World Bank (2008): Democratic Republic of Congo: Growth with Governance in Mining Sector, May 2008.

World Economic Forum (2011): Global Risks 2011, Sixth Edition. An initiative of the Risk Response Network, Cologny/Geneva.

WTO (2010): World trade report 2010: Trade in natural resources, Geneva. 
Annex- international initiatives and coverage of the value chain of coltan

\begin{tabular}{|c|c|c|c|c|c|c|}
\hline Initiative & Action description & $\begin{array}{l}\text { Actors respon- } \\
\text { sible }\end{array}$ & $\begin{array}{l}\text { Part of supply } \\
\text { chain }\end{array}$ & $\begin{array}{l}\text { Synergies with other } \\
\text { actions }\end{array}$ & Relevance for Central Africa & Risks \\
\hline $\begin{array}{l}\text { UN-EU partnership } \\
\text { on natural industries } \\
\text { and conflict preven- } \\
\text { tion }\end{array}$ & $\begin{array}{l}\text { Aims at ensuring inclusion of } \\
\text { conflict prevention and sensitivity } \\
\text { in NRM programs. It provides a } \\
\text { framework and technical assis- } \\
\text { tance useful to EU and UN } \\
\text { agencies to plan and design } \\
\text { intervention strategies where } \\
\text { extractive industries are driving } \\
\text { factors of the conflict }\end{array}$ & EU and UN & $\begin{array}{l}\text { UN and the EU, } \\
\text { extractive industries, } \\
\text { governments }\end{array}$ & $\begin{array}{l}\text { EITI, capacity build- } \\
\text { ing/technical assistance }\end{array}$ & $\begin{array}{l}\text { DRC is one of the country of operation. Although } \\
\text { Guidance Notes, training manuals, and online self- } \\
\text { paced learning tool are available, it will not benefit } \\
\text { from training modules for UN and EU field staff, as } \\
\text { well as local partners, which will take place in four } \\
\text { pilot countries: Timor Leste, Liberia, Peru and } \\
\text { Guinea-Conakry. However, in } 2008 \text { UNEP estab- } \\
\text { lished a Country Programme aiming "to assist the } \\
\text { government of DR Congo in its post-conflict } \\
\text { recovery and sustainable development" }\end{array}$ & $\begin{array}{l}\text { contribution of other key parties } \\
\text { is needed in order to achieve a } \\
\text { peaceful outcome in a coordinat- } \\
\text { ed and constructive manner }\end{array}$ \\
\hline EITI, EITI++ & $\begin{array}{l}\text { disclosure of public reve- } \\
\text { nues/expenses }\end{array}$ & $\begin{array}{l}\text { Governments } \\
\text { and companies }\end{array}$ & $\begin{array}{l}\text { Local companies } \\
\text { (comptoires/mining } \\
\text { companies) }\end{array}$ & $\begin{array}{l}\text { Capacity building pro- } \\
\text { grammes, initiatives sup- } \\
\text { porting transparency in the } \\
\text { value } \\
\text { chain(certification/chain of } \\
\text { custody assurance) }\end{array}$ & $\begin{array}{l}\text { DRC was accepted as candidate country in 2008. In } \\
2011 \text { its Candidate status was renewed by the EITI } \\
\text { Board. In March } 2013 \text { the country will be required } \\
\text { to comply with the } 2011 \text { edition of the EITI Rules } \\
\text { for EITI Validation for. Zambia, Mozambique and } \\
\text { Tanzania are the other Candidate countries in the } \\
\text { region }\end{array}$ & $\begin{array}{l}\text { It covers only one part of a } \\
\text { broader resource management } \\
\text { process. Problems in implementa- } \\
\text { tion due to the fragmentation of } \\
\text { state organizations }\end{array}$ \\
\hline $\begin{array}{l}\text { OECD/UN } \\
\text { due diligence }\end{array}$ & $\begin{array}{l}\text { Due diligence framework and } \\
\text { practical guidance on how to } \\
\text { manage risks }\end{array}$ & $\begin{array}{l}\text { Up/down- } \\
\text { stream opera- } \\
\text { tors }\end{array}$ & $\begin{array}{l}\text { Up/down-stream } \\
\text { operators }\end{array}$ & $\begin{array}{l}\text { Promotes the use of } \\
\text { schemes for traceability } \\
\text { (iTSCi), EITI }\end{array}$ & $\begin{array}{l}\text { The OECD, the ICGLR and the UN Group of } \\
\text { Experts on the DRC are cooperating in the imple- } \\
\text { mentation of the Guidance in Africa's Great Lakes } \\
\text { region. Currently, } 82 \text { companies and industry } \\
\text { associations are volunteering taking part in the pilot }\end{array}$ & $\begin{array}{l}\text { Too burdensome requirements, } \\
\text { might push companies from } \\
\text { OECD countries out of the sector }\end{array}$ \\
\hline $\begin{array}{l}\text { Capacity building of } \\
\text { governments (e.g. } \\
\text { Promines -Programme } \\
\text { intégré et multisecto- } \\
\text { riel de développement } \\
\text { du secteur minier en } \\
\text { RDC ) } \\
\end{array}$ & $\begin{array}{l}\text { Strengthening capacity of key instit } \\
\text { manage mineral sector, improving } \\
\text { investment and socio-economic ben }\end{array}$ & $\begin{array}{l}\text { Local institu- } \\
\text { tions, interna- } \\
\text { tional donors }\end{array}$ & $\begin{array}{l}\text { Local institutions, } \\
\text { business environ- } \\
\text { ment }\end{array}$ & $\begin{array}{l}\text { Attends to gaps in EITI, } \\
\text { supports the creation of } \\
\text { traceability systems }\end{array}$ & PROMINES was launched in 2009 in DRC & $\begin{array}{l}\text { Difficult implementation envi- } \\
\text { ronment in the region (e.g. situa- } \\
\text { tion in DRC), limited resources } \\
\text { for too wide scope }\end{array}$ \\
\hline $\begin{array}{l}\text { Certified Trading } \\
\text { Chains (CTC) }\end{array}$ & $\begin{array}{l}\text { Ensure chain of custody for } \\
\text { producers and buyers (verifica- } \\
\text { tion of origin and trade volume } \\
\text { analysis, independent audits); on- } \\
\text { the-ground assessment of mining } \\
\text { conditions }\end{array}$ & $\begin{array}{l}\text { BRG and the } \\
\text { local ministry of } \\
\text { mines (DRC, } \\
\text { Rwanda) }\end{array}$ & $\begin{array}{l}\text { Mining production } \\
\text { and trade (focus on } \\
\text { companies' conces- } \\
\text { sions - LSM) }\end{array}$ & $\begin{array}{l}\text { Capacity building pro- } \\
\text { grammes, fingerprinting } \\
\text { process }\end{array}$ & $\begin{array}{l}\text { Implementation of the scheme has been satisfactory } \\
\text { in Rwanda. Concerning DRC, the pilot project in } \\
\text { South Kivu is at an earlier stage. CTC offices have } \\
\text { been created in Kinshasa and Bukavu and work- } \\
\text { shops held to better define the criteria for the } \\
\text { implementation of the initiative }\end{array}$ & $\begin{array}{l}\text { Capacity building needed, multi- } \\
\text { ple stakeholders involved can } \\
\text { hamper the process }\end{array}$ \\
\hline iTSCi & $\begin{array}{l}\text { Ensure traceability of minerals } \\
\text { (phase I- introduction of due } \\
\text { diligence procedures, written } \\
\text { documentation, independent } \\
\text { audits; phase II- "bag and tag } \\
\text { system" of traceability) }\end{array}$ & $\begin{array}{l}\text { Initiative of the } \\
\text { tin smelting } \\
\text { industry }\end{array}$ & $\begin{array}{l}\text { Suppliers and ex- } \\
\text { porters of minerals } \\
\text { (in particular ASM) }\end{array}$ & $\begin{array}{l}\text { Possible interaction with } \\
\text { Capacity building pro- } \\
\text { grammes, EICC/GeSi, } \\
\text { OECD/UN due diligence } \\
\text { guidelines. Could be } \\
\text { integrated in CTC as } \\
\text { traceability scheme. }\end{array}$ & $\begin{array}{l}\text { Pilot projects started in south Kivu in 2010, but } \\
\text { have been stopped due to the mining suspension } \\
\text { from September } 2010 \text {. Since } 2011 \text {, implementation } \\
\text { phase in Rwanda and the southern DRC province } \\
\text { of Katanga. The scheme may be extended to Bu- } \\
\text { rundi and Uganda, if funding is assured, and even- } \\
\text { tually the entire Great Lakes Region }\end{array}$ & $\begin{array}{l}\text { Security of mining sites, com- } \\
\text { mercial visibility, need to publish } \\
\text { data for awareness raising }\end{array}$ \\
\hline
\end{tabular}




\begin{tabular}{|c|c|c|c|c|c|c|}
\hline $\begin{array}{l}\text { Analytical Fingerprint } \\
\text { (AFP) }\end{array}$ & $\begin{array}{l}\text { Independent mineral traceability } \\
\text { tool }\end{array}$ & $\begin{array}{l}\text { Up to now: } \\
\text { BRG }\end{array}$ & Mining and trade & $\begin{array}{l}\text { Forms part of CTC certifi- } \\
\text { cation scheme; can be } \\
\text { linked to iTCSi }\end{array}$ & $\begin{array}{l}\text { Pilot projects are being implemented in Rwanda. } \\
\text { The system is supposed to be extended to other } \\
\text { ICGLR countries among which DRC }\end{array}$ & $\begin{array}{l}\text { Complex and costly implementa- } \\
\text { tion, stakeholders facilitation and } \\
\text { institutional support needed }\end{array}$ \\
\hline $\begin{array}{l}\text { Global e- } \\
\text { Sustainability Initia- } \\
\text { tive and Electronic } \\
\text { Industry Citizenship } \\
\text { Coalition - Conflict- } \\
\text { Free Smelter (CFS) } \\
\text { protocol }\end{array}$ & $\begin{array}{l}\text { GeSI/ EICC offer a tool relating } \\
\text { to smelter due diligence require- } \\
\text { ments and support for certifica- } \\
\text { tion of smelters. }\end{array}$ & $\begin{array}{l}\text { Initiative of } \\
\text { electronics } \\
\text { industry }\end{array}$ & Smelters & $\begin{array}{l}\text { Link with mineral certifi- } \\
\text { cation schemes (iTSCi and } \\
\text { CTC) }\end{array}$ & $\begin{array}{l}\text { The mechanism concerns smelters sourcing from } \\
\text { DRC and adjoining countries }\end{array}$ & Complexity of ITC supply chain \\
\hline $\begin{array}{l}\text { ICGLR certification } \\
\text { scheme }\end{array}$ & $\begin{array}{l}\text { International Conference of the } \\
\text { Great Lakes Region, Regional } \\
\text { certificate of origin scheme, } \\
\text { harmonization, promotion of } \\
\text { dialogue }\end{array}$ & ICGLR & $\begin{array}{l}\text { Local produc- } \\
\text { ers/traders }\end{array}$ & $\begin{array}{l}\text { Complementarity with } \\
\text { other point of origin certi- } \\
\text { fication schemes (CTC, } \\
\text { iTSCi) }\end{array}$ & $\begin{array}{l}\text { DRC and Rwanda are member States of the } \\
\text { ICGLR, together with Angola, Burundi, Central } \\
\text { African Republic, Republic of Congo, Kenya, } \\
\text { Uganda, Sudan, Tanzania, Zambia. The countries } \\
\text { are all signatories of the Regional Initiative against } \\
\text { the Illegal Exploitation of Natural Resources } \\
\text { providing the framework for actions in the domain } \\
\text { of natural resources exploitation }\end{array}$ & Ownership issues \\
\hline Bans & $\begin{array}{l}\text { mining/export of the mineral is } \\
\text { prevented }\end{array}$ & $\begin{array}{l}\text { Governments/ } \\
\text { international } \\
\text { community }\end{array}$ & $\begin{array}{l}\text { Extraction phase or } \\
\text { exports from the } \\
\text { producing country }\end{array}$ & $\begin{array}{l}\text { May be symbolic part of } \\
\text { broader action }\end{array}$ & $\begin{array}{l}\text { A mining ban was instituted in DRC from Septem- } \\
\text { ber } 2010 \text { to March } 2011\end{array}$ & $\begin{array}{l}\text { Bringing further economic hard- } \\
\text { ship for people, costly and } \\
\text { difficult to enforce }\end{array}$ \\
\hline Dodd Frank act & $\begin{array}{l}\text { Legal obligation on US compa- } \\
\text { nies reporting to SEC to declare } \\
\text { use of "conflict minerals" }\end{array}$ & $\begin{array}{l}\text { SEC, SEC } \\
\text { reporting com- } \\
\text { panies }\end{array}$ & $\begin{array}{l}\text { SEC reporting } \\
\text { companies with } \\
\text { activities in explo- } \\
\text { ration, discovery, } \\
\text { development and } \\
\text { extraction, pro- } \\
\text { cessing, export and } \\
\text { other significant } \\
\text { actions }\end{array}$ & $\begin{array}{l}\text { Due diligence guidelines } \\
\text { and iTSCi }\end{array}$ & $\begin{array}{l}\text { Dodd Frank section } 1502 \text { is a disclosure require- } \\
\text { ment, concerning sourcing conflict minerals from } \\
\text { DRC or adjoining countries }\end{array}$ & $\begin{array}{l}\text { Compliance issues, questionable } \\
\text { impact on Congolese people. }\end{array}$ \\
\hline $\begin{array}{l}\text { EC Accounting and } \\
\text { Transparency Direc- } \\
\text { tives }\end{array}$ & $\begin{array}{l}\text { The rules of the Directives re- } \\
\text { quire extractive industry and } \\
\text { forestry companies to declare } \\
\text { payments (production entitle- } \\
\text { ments, taxes or profit, royalties, } \\
\text { dividends, license fees, other } \\
\text { benefits to governments) to } \\
\text { governments in every country } \\
\text { they operate and on a project-by- } \\
\text { project base }\end{array}$ & $\begin{array}{l}\text { Listed and large } \\
\text { or public inter- } \\
\text { est non-listed } \\
\text { companies } \\
\text { active in the } \\
\text { extractive or } \\
\text { logging indus- } \\
\text { tries }\end{array}$ & $\begin{array}{l}\text { Extractive and } \\
\text { logging companies } \\
\text { with activities in } \\
\text { exploration, discov- } \\
\text { ery, development } \\
\text { and extraction } \\
\text { phases }\end{array}$ & $\begin{array}{l}\text { EITI but also other certifi- } \\
\text { cation schemes and due } \\
\text { diligence guidelines }\end{array}$ & $\begin{array}{l}\text { The directives refer to companies in the extractive } \\
\text { industry or forestry in whatever country they } \\
\text { operate }\end{array}$ & $\begin{array}{l}\text { Debated points (covering compa- } \\
\text { nies in other sectors, disclosure of } \\
\text { more information, elimination of } \\
\text { exemptions, etc.). The proposal } \\
\text { has to be approved by the Euro- } \\
\text { pean Parliament and Council and } \\
\text { implemented in the Member } \\
\text { States. }\end{array}$ \\
\hline Starec plan & $\begin{array}{l}\text { Rehabilitation and regulation of } \\
\text { mining. Establishments of mar- } \\
\text { ketplaces (centres de negoce) in } \\
\text { key mining areas }\end{array}$ & $\begin{array}{l}\text { Government of } \\
\text { DRC, artisanal } \\
\text { miners and their } \\
\text { associations } \\
\end{array}$ & $\begin{array}{l}\text { Traders, merchants, } \\
\text { diggers, mineral and } \\
\text { state authorities }\end{array}$ & & The programme covers DRC & $\begin{array}{l}\text { Challenge on how to manage } \\
\text { security }\end{array}$ \\
\hline
\end{tabular}

Source: Authors' elaboration of different sources. 
